\title{
Peningkatan Pengetahuan tentang Jenis Penyakit di Usia Lansia pada Kelompok Lansia
}

\author{
Ni'matul Ulya \\ Email: renex_cubby@yahoo.co.id \\ DIII Kebidanan, Akademi Kebidanan Harapan Ibu Pekalongan, Indonesia \\ Jl. Sriwijaya No. 7 Pekalongan \\ Telp. (0285) 4416108
}

\begin{abstract}
Abstrak
Keberhasilan pembangunan nasional khususnya pembangunan nasional bidang kesehatan salah satunya terlihat dari semakin meningkatnya usia harapan hidup masyarakat Indonesia. Sebelas persen dari 6,9 milyar penduduk dunia adalah lansia. Indonesia mengalami peningkatan jumlah penduduk lansia dari 18 juta jiwa (7,56\%) pada tahun 2010 , menjadi 25,9 juta jiwa $(9,7 \%)$ pada tahun 2019, dan diperkirakan akan terus meningkat dimana tahun 2035 menjadi 48,2 juta jiwa $(15,77 \%)$. Lansia identik dengan berbagai penurunan status kesehatan terutama status kesehatan fisik. Pada umumnya cukup sulit mengenali secara dini permasalahan kesehatan terutama penyakit yang biasa muncul yang terjadi pada usia lanjut. Permasalahan kesehatan dapat dicegah dengan pola hidup yang sehat sehingga perlu dilakukan peningkatan pengetahuan tentang penyakit yang biasa muncul pada masa lansia. Metode yang digunakan dalam kegiatan pengabdian masyarakat ini melalui kegiatan ceramah pada kelompok Lansia Aisyiyah di Kota Pekalongan. Hasil dari kegiatan ini pengetahuan lansia mengalami peningkatan sebanyak $36,3 \%$ untuk penyebab penyakit rematik, 27,3\% gejala rematik dan 30,3\% diit makanan penyakit rematik; 27,3\% untuk penyebab dan diit makanan penyakit asam urat, dan sebanyak 36,3\% tentang gejala asam urat; 33,3\% untuk penyebab penyakit hipertensi, $36,3 \%$ gejala dan $27,3 \%$ diit makanan penyakit hipertensi; sebanyak $27 \%$ tentang penyebab penyakit Diabetes Mellitus (DM), 27,3\% gejala dan 30,3\% untuk diit makanan penyakit DM.
\end{abstract}

Kata kunci: lansia; peningkatan pengetahuan; penyakit lansia.

\begin{abstract}
The success of national development, especially national development in the health sector, can be seen from the increasing life expectancy of the Indonesian people. Eleven percent of the world's 6.9 billion population are elderly. Indonesia experienced an increase in the number of elderly people from 18 million (7.56\%) in 2010, to 25.9 million (9.7\%) in 2019, and is expected to continue to increase where in 2035 to 48.2 million people $(15.77 \%)$. The elderly are identical with various decreases in health status, especially physical health status. In general, it is quite difficult to recognize health problems early on, especially diseases that usually arise in old age. Health problems can be prevented with a healthy lifestyle, so it is necessary to increase knowledge about diseases that commonly occur in old age. The method used in this community service activity is through a lecture to the Elderly Aisyiyah group in Pekalongan City. The results of this activity increased knowledge of the elderly by $36.3 \%$ for the causes of rheumatic disease, $27.3 \%$ for rheumatic symptoms and $30.3 \%$ in the diet of rheumatic diseases; $27.3 \%$ for the causes and diet of gout, and $36.3 \%$ for the symptoms of gout; $33.3 \%$ for causes of hypertension, $36.3 \%$ for symptoms and $27.3 \%$ for hypertension disease diet; as much as $27 \%$ about the cause of Diabetes Mellitus (DM), $27.3 \%$ symptoms and $30.3 \%$ for diets with diabetes mellitus.
\end{abstract}

Keywords: elderly; increased knowledge; elderly disease. 


\section{Pendahuluan}

Proses penuaan merupakan suatu hal yang wajar, dan ini adalah dialami oleh semua orang yang dikaruniai umur panjang, hanya cepat dan lambatnya proses tersebut tergantung pada usia individu. Secara teori perkembangan manusia yang dimulai dari masa bayi, anak, remaja, dewasa, tua, dan akhirnya masuk fase usia lanjut dengan umur diatas 60 tahun. Stanhope dan Lancaster (1) mengatakan lansia sebagai populasi berisiko memiliki tiga karakteristik risiko kesehatan yaitu, risiko biologi termasuk risiko terkait usia, risiko sosial dan lingkungan serta risiko perilaku atau gaya hidup. Indonesia mengalami peningkatan jumlah penduduk lansia dari 18 juta jiwa $(7,56 \%)$ pada tahun 2010 , menjadi 25,9 juta jiwa $(9,7 \%)$ pada tahun 2019, dan diperkirakan akan terus meningkat dimana tahun 2035 menjadi 48,2 juta jiwa $(15,77 \%)^{(2)}$.

Lansia identik dengan berbagai penurunan status kesehatan terutama status kesehatan fisik. Berbagai teori tentang proses menua menunjukkan hal yang sama. Status kesehatan lansia yang menurun seiring dengan bertambahnya usia akan memengaruhi kualitas hidup lansia.. Dilihat dari angka kesakitan penduduk lansia, maka pada tahun 2012 terdapat $26,93 \%$ penduduk yang sakit yang artinya bahwa dari setiap 100 orang lansia terdapat 27 orang di antaranya mengalami sakit. Meskipun ada peningkatan derajad kesehatan pada kelompok penduduk lansia namun secara umum hampir di semua propinsi derajad kesehatan penduduk lansia masih cenderung sangat rendah. Rendahnya derajad kesehatan salah satunya dipengaruhi oleh proses alami dari menua (aging process).
Berdasarkan data Riskesdas tahun 2018, penyakit yang terbanyak pada lansia untuk penyakit tidak menular antara lain: hipertensi, masalah gigi, penyakit sendi, masalah mulut, diabetes mellitus, penyakit jantung dan stroke, dan penyakit menular antara lain seperti ISPA, diare, dan pneumonia. Selain penyakit tidak menular dan menular, lansia berisiko untuk masalah gizi terutama gizi lebih, gangguan mental emosional, depresi, serta demensia ${ }^{(3)}$.

Pada umumnya cukup sulit mengenali secara dini permasalahan kesehatan yang terjadi pada usia lanjut ${ }^{(4)}$. Kebanyakan gejala dan tanda yang muncul tidak spesifik sehingga sering kali masalah dikenali ketika sudah berlanjut. Hal ini semakin sulit karena munculnya tanda dan gejala natural dari proses menua dan kondisi kronis yang kompleks yang dapat mengaburkan tanda atau gejala yang sebenarnya menunjukkan adanya permasalahan kesehatan. Keadaan kadang menjadi tambah sulit karena sebagian masyarakat Indonesia juga belum memiliki kesadaran penuh untuk peduli terhadap upaya deteksi dini terhadap potensi masalah yang akan dihadapinya.

Sebelum dilakukan pengabdian masyarakat ini, para lansia diberikan pertanyaann seputar penyakit yang sering muncul pada masa lansia seperti penyakit kencing manis (Diabetes Mellitus), tekanan darah tinggi (Hipertensi), rematik. Sebagian besar lansia yakni kurang lebih 27 orang belum mengetahui secara jelas penyebab, tanda dan gejala serta cara mengatasi atau mencegah ketiga penyakit tersebut. 


\section{Metode}

Kegiatan

peningkatan

pengetahuan tentang jenis penyakit di usia lansia merupakan salah satu rangkaian kegiatan pengabdian kepada masyarakat yang dilakukan penulis dengan mitra kelompok lansia Aisyiyah di Kota Pekalongan. Dalam kegiatan ini dilakukan penyuluhan dengan metode ceramah tentang berbagai jenis penyakit yang biasa muncul pada masa lansia diantaranya penyakit rematik, asam urat, hipertensi dan penyakit kencing manis. Jumlah lansia yang hadir pada kegiatan ini sebanyak 33 lansia. Penilaian dilakukan dengan menggunakan kuesioner pre test dan post test yang disebarkan dengan bantuan mahasiswa. Di akhir kegiatan ini, penulis memberikan sesi tanya jawab kepada peserta terkait materi yang telah diberikan.

\section{Hasil dan Pembahasan}

Kegiatan pengabdian masyarakat ini dilaksanakan di Masjid Al-Ikhlas Kramatsari Kota Pekalongan. Sebagian besar lansia yakni sejumlah 27 lansia belum mengetahui dengan jelas mengenai penyebab dan cara mengatasi penyakit yang biasa muncul pada lansia.

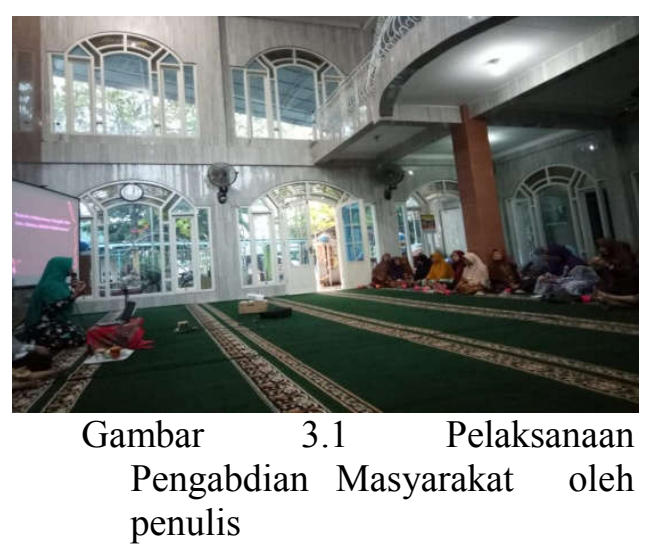

Kegiatan tersebut dinilai dapat meningkatkan pengetahuan dan informasi lansia mengenai jenis penyakit yang biasa muncul pada masa lansia yang bisa terlihat pada Tabel 3.1 di bawah ini

Tabel 3.1 Hasil peningkatan pengetahuan kelompok lansia tentang jenis penyakit pada masa lansia

\begin{tabular}{llcc}
\hline \multicolumn{1}{c}{ Item } & Pre test & Post test & Peningkatan \\
\hline $\begin{array}{l}\text { a. } \\
\text { Penyakit Rematik }\end{array}$ & $48,5 \%$ & $84,8 \%$ & $36,3 \%$ \\
\hline Penyebab & $60,6 \%$ & $87,9 \%$ & $27,3 \%$ \\
\hline Gejala & $57,6 \%$ & $87,9 \%$ & $30,3 \%$ \\
\hline $\begin{array}{l}\text { Diit makanan } \\
\text { Penyakit Asam Urat } \\
\text { Penyebab }\end{array}$ & $63,6 \%$ & $90,9 \%$ & $27,3 \%$ \\
\hline Gejala & $57,6 \%$ & $93,9 \%$ & $36,3 \%$ \\
\hline Diit makanan & $54,5 \%$ & $81,8 \%$ & $27,3 \%$ \\
\hline c. $\begin{array}{l}\text { Penyakit Hipertensi } \\
\text { Penyebab }\end{array}$ & $60,6 \%$ & $93,9 \%$ & $33,3 \%$ \\
\hline Gejala & $48,5 \%$ & $84,8 \%$ & $36,3 \%$ \\
\hline Diit makanan & $60,6 \%$ & $87,9 \%$ & $27,3 \%$ \\
\hline d. Penyakit Diabetes Mellitus (DM) & $69,7 \%$ & $96,7 \%$ & $27 \%$ \\
\hline Penyebab & $54,5 \%$ & $81,8 \%$ & $27,3 \%$ \\
\hline Gejala & $57,6 \%$ & $87,9 \%$ & $30,3 \%$ \\
\hline Diit makanan & & &
\end{tabular}


Dari tabel 3.1 di atas menunjukkan bahwa antusiasme peserta cukup besar selama kegiatan berlangsung. Antusiasme tersebut ditunjukkan dengan banyaknya pertanyaan yang mereka ajukan dan tidak sedikit peserta yang saling sharing mengenai keluhan yang mereka rasakan. Hasil yang didapat dari kegiatan ini terjadi peningkatan pengetahuan tentang penyebab penyakit rematik sebesar $36,3 \%$, gejala penyakit rematik sebesar $27,3 \%$ dan $30,3 \%$ tentang diit makanan pada penderita rematik. Untuk penyakit asam urat ada peningkatan pengetahuan tentang penyebab sebesar $27,3 \%$, gejala $36,3 \%$ dan diit makanan bagi penderita asam urat sebesar 27,3\%, sedangkan penyakit hipertensi terjadi peningkatan penyebab sebanyak $33,3 \%$, gejala hipertensi $36,3 \%$ dan diit makanan $27,3 \%$. Pengetahuan lansia tentang penyebab penyakit DM juga meningkat sebanyak $27 \%$, gejala $27,3 \%$ dan pengetahuan diit makanan bagi penderita DM sebesar $30,3 \%$.

Hal ini sesuai dengan teori yang dikemukakan oleh Mahmoudi et al (2018) bahwa pendidikan kesehatan (penyuluhan) bisa efektif digunakan terutama untuk pasien lanjut usia dalam meningkatkan kesehatan, terutama dalam tanggung jawab untuk berperilaku sehat, beraktivitas fisik dan manajemen stress ${ }^{(5)}$. Hasil tersebut sejalan dengan penelitian yang telah dilakukan oleh penulis tentang "Pengaruh Pendidikan Kesehatan tentang Menopause Terhadap Tingkat Pengetahuan Ibu Pra Menopause" dimana sebanyak $34,3 \%$ responden berpengetahuan cukup sebelum diberikan penyuluhan dan setelah diberikan penyuluhan menurun menjadi
$28,3 \%{ }^{(6)}$. Dengan diberikannya informasi mengenai jenis penyakit yang biasa muncul pada lansia di kelompok Lansia Aisyiyah mengalami peningkatan pengetahuan pada kelompok tersebut. Pernyataan ini sesuai dengan teori yang disampaikan Gordon B Davis bahwa dengan pemberian informasi membantu menambah pengetahuan dan mengurangi ketidak pastian pemakai informasi ${ }^{(7)}$.

Sebagian besar lansia di kelompok lansia Aisyiyah sudah sudah banyak yang tahu akan jenis penyakit yang biasa muncul pada lansia yang cukup baik terbukti dengan persentase pre test. Akan tetapi, pengetahuan seseorang perlu ditingkatkan terus menerus dan perlu diterapkan dalam kehidupan sehari-hari sehingga derajat kesehatannya dapat meningkat ${ }^{(8)}$.

\section{Kesimpulan}

Pelaksanaan pengabdian kepada masyarakat yang dilakukan oleh penulis dengan metode penyuluhan kesehatan dapat meningkatkan pengetahuan dan pemahaman lansia mengenai berbagai jenis penyakit yang sering muncul pada usia lansia sehingga mereka dapat mencegah terjadinya penyakit dan dapat mengelola penyakitnya jika sudah menderita agar tidak menjadi parah/berat. 


\section{Daftar Pustaka}

[1] M. Stanhope and J. Lancaster, 9th ed. Missouri:: Elsevier, 2016.

[2] Badan Pusat Statistik (BPS), Proyeksi penduduk Indonesia population projection 2010 2035. Jakarta: Badan Pusat Statistik, 2013.

[3] Riset Kesehatan Dasar (Riskesdas), Badan Penelitian dan Pengembangan Kesehatan Kementerian RI tahun 2018. 2018.

[4] Vicky, "The Unique Needs of Elderly Patients in the Emergency Department (Part 2)," Emerg. Nurs., 2012. $\mathrm{http}: / /$ allnurses. com/emergencynursing/theunique-needs 761193.html. (accessed Jan, 2020)
[5] H. N. Mahmoudi and D. Mardani, "Comparison of the Health Promoting Life Style in Patients Candidate for Coronary Artery Bypass Graft and Percutaneous Coronary Intervention in Isfahan Shahid Chamran Hospital, 2017," Rev. Latinoam. Hipertens,, vol. 13, no. 6, pp. 520-525, 2018.

[6] N. Ulya and P. R. Meikawati, "Pengaruh Pendidikan Kesehatan tentang Menopause Terhadap Tingkat Pengetahuan Ibu Pra Menopause," J. Kesehat. Ibu dan Anak Akbid An-Nur, vol. 4, no. 1, 2019.

[7] J. Hutahaean, "Konsep Sistem Informasi," Deepublish, 2015.

[8] S. Ati, Nurdien, Kristanto, and Taufik, Pengantar Konsep Informasi, Data, dan Pengetahuan. 2014. 